\title{
Sistem Klasifikasi Kelor dalam Etnobotani Masyarakat Wolio
}

\author{
Wa Ode Winesty Sofyani \\ Universitas Halu Oleo Kendari - Indonesia
}

\begin{abstract}
This article studies about ethnobotany kelor (Moringa oleifera) of Wolio people in Baubau, Southeast Sulawesi Province. The aim of this research is to know how the classification systems of kelor plants in Wolio people and why the kelor plants to be classified. Data collection of this research is using ethnography method, in-depth interview and participatory observation to know the view of Wolio people concern with kelor. The result of this research shows that kelor classification system of Wolio people consists of females and males. According to Wolio people, the existence of kelor classification due to a difference of colour, type, size, and taste. The use of kelor gender as kelor classification system reflects the life of Wolio people.
\end{abstract}

Artikel ini membahas tentang etnobotani kelor (Moringa oleifera) di kalangan masyarakat Wolio, Kota Baubau, Provinsi Sulawesi Tenggara. Penelitian ini bertujuan untuk mengetahui bagaimana sistem klasifikasi tanaman kelor di masyarakat Wolio, dan mengapa tanaman kelor diklasifikasikan. Pengumpulan data dalam penelitian ini menggunakan metode etnografi, karena untuk mengetahui pandangan masyarakat Wolio mengenai kelor digunakan teknik wawancara mendalam, dan pengamatan terlibat. Hasil penelitian menunjukkan bahwa sistem klasifikasi kelor pada masyarakat Wolio terdiri atas kelor perempuan dan laki-laki. Adanya pengklasifikasian kelor karena terdapat perbedaan: warna, bentuk, ukuran, dan rasa menurut pandangan masyarakat Wolio. Genderisasi kelor sebagaimana dalam sistem klasifikasi kelor sesungguhnya merefleksikan kehidupan dan dunia masyarakat Wolio.

Keywords: kelor; ethnobotany; classification; gender; reflection

Korepondensi Penulis: Wa Ode Winesty Sofyani (sofyani.winesty@gmail.com). Jurusan Antropologi, Fakultas Ilmu Budaya, Universitas Halu Oleo Kendari. Jl. H.E.A. Mokodompit, Kodya Kendari, Sulawesi Tenggara, Indonesia 93232. 


\section{Pendahuluan}

Tanaman kelor (Moringa oleifera) merupakan salah satu tanaman yang telah lama dikenal, dibudidayakan, dan digunakan oleh masyarakat Wolio di Baubau, Provinsi Sulawesi Tenggara. Dalam etnobotani Wolio, kelor tidak saja diberi nama tertentu, multiguna, akan tetapi juga diklasifikasikan. Adanya sistem klasifikasi mengenai kelor pada masyarakat Wolio menarik diteliti karena pada masyarakat lain yang juga membudidayakan dan menggunakan kelor seperti: Jawa, Madura, Bugis, dan lainnya tidak mengklasifikasikan kelor.

Salah satu studi yang menitikberatkan perhatiannya pada penggunaan tanaman-tanaman berdasarkan pandangan penduduk asli adalah etnobotani (Ford 1985; Young 2007). Etnobotani merupakan studi lintas disiplin ilmu, kolaborasi berbagai disiplin ilmu diantaranya: botani, arkeologi, antropologi, ekologi, konservasi, biologi, farmakologi, ekonomi, yang selama ini telah banyak berkonstribusi di antaranya di bidang makanan, obat, tekstil, dan lingkungan (Jahn 1991; Senchina 2006). Selain mengkaji bagaimana sudut pandang penduduk asli menggunakan tanaman-tanaman di lingkungannya, etnobotani juga mengkaji bagaimana penduduk asli mengklasifikasikan tanaman-tanaman di lingkungannya (Harris 2008). Menurut Ford (1985) etnobotani adalah ilmu yang mengidentifikasi tanaman apa yang bermakna, bagaimana budaya mengklasifikasi tanaman, bagaimana pandangan masyarakat terhadap tanaman yang sesungguhnya merefleksikan dunia mereka.

Studi yang fokus pada sistem klasifikasi telah dilakukan oleh para ahli etnobotani antara lain:
Glick (1964), Berlin, Breedlove, dan Raven (1968), Frisch (1968), Perchonock dan Werner (1969), Fleuret (1980), Lira dan Caballero (2002), Ghosal dan Chakraborty (2009). Berdasarkan penelitian-penelitian yang telah dilakukan, Butts (1946) lalu menyimpulkan bahwa adanya sistem klasifikasi pada dasarnya bertujuan untuk memudahkan pengidentifikasian objek sesuai dengan karakternya masingmasing. Berbeda halnya dengan teori Butts, ahli lain mengatakan bahwa klasifikasi atau kategorisasi merupakan aturan dari berbagai hal yang berbeda yang diperlakukan seolah-olah ekuivalen, sehingga dengan melakukan kategorisasi akan mengurangi kompleksitas pengalaman manusia (Spradley 1997:125). (Glick 1964: 274-275) mengemukakan bahwa pengklasifikasian adalah sebagai upaya penyederhanaan dari berbagai perbedaan karakteristik benda, baik hewan maupun tanaman. Butts (1946) mengatakan pula di balik klasifikasi benda sesungguhnya ada tujuan lain. Klasifikasi dibuat pada prinsipnya bertujuan sebagai dasar logika untuk penamaan atau pengidentifikasian benda-benda.

Klasifikasi tanaman kelor di kalangan masyarakat Wolio terdiri atas kelor perempuan dan kelor laki-laki. Klasifikasi tersebut hingga kini masih tetap berlaku di tengah masyarakat, dan secara kultural berpengaruh dalam pemaknaan masing-masing kelor. Mengacu pada teori Butts bahwa di balik klasifikasi benda sesungguhnya ada tujuan lain, dan klasifikasi pada prinsipnya mempunyai dasar logika dalam penamaannya, maka pengklasifikasian kelor di kalangan masyarakat Wolio boleh jadi tersembunyi sebuah ideologi. 
Penelitian ini dilakukan di Kota Baubau, Provinsi Sulawesi Tenggara, dengan pertimbangan di daerah ini kelor sudah lama dikenal, banyak dibudidayakan, dan digunakan untuk berbagai tujuan. Selain itu, hal yang tak kalah menariknya karena kelor selama ini diklasifikasikan atas kelor perempuan dan laki-laki. Metode yang digunakan dalam penelitian ini adalah metode etnografi. Oleh karena itu, teknik pengamatan terlibat, wawancara mendalam dengan menekankan penguasaan bahasa lokal sangat diutamakan (Spindler dan Spindler 1985; Spradley 1997; Tedlock 2011).

Informan dalam penelitian adalah penduduk asli Baubau, yaitu masyarakat Wolio. Informan terdiri atas: petani kelor, pengguna kelor, budayawan Wolio baik dari kaum perempuan maupun laki-laki. Analisis data yang utama dan penting yaitu melakukan analisis domain kelor, karena menurut Spradley (1997:140-54) tujuan analisis domain adalah untuk mengidentifikasi kategori-kategori pemikiran melalui hubungan semantik. Dari analisis ini, apa yang tersirat akan dapat tersurat karena makna-makna budaya dapat terungkap pada akhirnya

\section{Gambaran Umum Masyarakat Wolio}

Masyarakat Wolio merupakan salah satu sub etnis Buton, yang bermukim di Kota Baubau, Pulau Buton, Sulawesi Tenggara. Sebagai penduduk asli Baubau, masyarakat Wolio bermukim di lokasi yang sangat strategis karena selain berada di pusat pemerintahan eks Kerajaan Wolio atau Kesultanan Buton, juga sejak dulu merupakan daerah transit berbagai kapal dari Malaka ke Maluku atau sebaliknya, yang hendak berdagang rempah-rempah. Dewasa ini Baubau tidak saja dihuni oleh masyarakat Wolio, Katobengke dan Laporo yang masing-masing mempunyai bahasa yang berbeda, akan tetapi juga oleh para pendatang dari berbagai sub etnis Buton di sekitar Baubau, dan etnis lain di Indonesia.

Kota Baubau dengan luas wilayah daratan kurang lebih $221.00 \mathrm{~km}^{2}$ serta luas laut $30 \mathrm{~km}^{2}$ memiliki wilayah yang bervariasi yaitu: pegunungan, perbukitan, tanah datar, dan pantai. Keadaan alamnya yang terdiri atas daratan dan laut, menyebabkan mata pencaharian penduduk selain terkait dengan aktifitas pertanian, kelautan, juga terkait dengan perdagangan, sektor jasa dan lainnya. Khusus dalam mata pencaharian bertani, aktifitas ini banyak dilakukan oleh masyarakat yang bertempat tinggal di pinggiran. Sebaliknya di kota sektor perdagangan, jasa dan lainnya lebih dominan.

Sekalipun pertanian yang dilakukan masyarakat umumnya masih tradisional dan lebih mengandalkan lahan kering dengan sistem tadah hujan, akan tetapi beberapa tanaman jangka panjang bernilai ekonomi tinggi cukup banyak yang mengusahakannya. Tanaman yang dimaksud terutama tanaman mete, kopi, coklat, kelapa, dan lainnya. Salah satu tanaman yang banyak dibudidayakan masyarakat yaitu tanaman kelor. Tanaman ini sekali pun tidak bernilai ekonomi tinggi, akan tetapi sangat disukai dan dibutuhkan masyarakat. Masyarakat Wolio umumnya gemar makan daun dan buah kelor. Menurut pandangan mereka kelor yang dibuat sayur, selain segar dan enak juga menyehatkan. Umumnya generasi tua akan menjadikan kelor 
sebagai sayur yang dikonsumsi sehari-hari. Sebaliknya generasi muda selain memilih jenis sayur kekinian (kol, wortel, sawi dan lain-lain) juga cukup kreatif memadukan kelor dengan mie instan. Bagi masyarakat Wolio mengkonsumsi kelor saat kuah kelor dalam keadaan hangat atau panas adalah hal yang baik. Hal ini karena pada saat yang demikian, keringat akan keluar.

Salah satu dampak majunya informasi dan teknologi dewasa ini, telah menyebabkan adanya perubahan di berbagai aspek kehidupan masyarakat Wolio. Salah satunya adalah perubahan penggunaan bahasa Wolio di kalangan keluarga Wolio, khususnya generasi milenial. Jika dahulu bahasa ibu yang digunakan seharihari adalah bahasa Wolio, kini telah beralih ke bahasa Indonesia. Demikian pula bahasa Wolio sebagai lingua franca di Kesultanan Buton kini nyaris tinggal kenangan.

Masyarakat Wolio merupakan penganut agama Islam, dan sebagai eks kesultanan situs sejarah yang menegaskan jika Islam pernah berpengaruh kuat di daerah ini dapat dilihat dari tinggalan sejarah dalam lokasi Benteng Keraton Wolio, di antaranya Mesjid Agung Keraton Wolio Buton, dan makam para raja dan para sultan. Pada awal berdirinya Kerajaan Wolio di awal abad ketiga belas, kerajaan ini dipimpin oleh seorang perempuan bernama Wa Kaa Kaa. Selanjutnya pemerintahan berikutnya juga dipimpin oleh perempuan bernama Bulawambona, yang merupakan putri dari Wa Kaa Kaa. Tiga raja yang juga masih merupakan keturunan raja pertama yaitu: Bataraguru, Tua Rade, dan Raja Mulae. Setelah sistem kerajaan beralih ke bentuk pemerintahan kesultanan tahun 1527, pemerintahan di Wolio lalu dipimpin oleh para sultan.

Ajaran Islam pertama kali masuk di Kerajaan Wolio diperkenalkan oleh ulama Syech Abdul Wahid dalam pelayaran perdagangannya dari Malaka ke Ternate melalui Solor, Nusa Tenggara Timur. Kedatangan Syech Abdul Wahid yang kedua kali, lalu membawa serta keluarganya hingga berlanjut pada pernikahan tiga putri beliau dengan laki-laki bangsawan Wolio. Tiga putri Syech Abdul Wahid yaitu: Nyai Hiba menikah dengan La Elangi/Dayanu Ikhsanuddin, (Sultan Buton keempat), Nyai Pula dengan La Bula (Kenepulu 1), dan Nyai Didi dengan La Singga (Sapati 1). Keturunan dari mereka ini kemudian menjadi sultan dan pembesar lainnya, serta menjadi penegak dinasti Qaim ad-Din (menegakkan agama) di Kesultanan Buton.

Penyebar ajaran Islam lainnya setelah Syech Abdul Wahid yakni Firuz Muhammad dan Sayyid Rabb atau lebih populer dengan sebutan Sayidi Raba. Sayidi Raba selain menjadi penasihat spiritual Sultan Sakiyuddin Darul Alam (sultan kesembilan belas) juga menikah dengan perempuan bangsawan Wolio. Setahun setelah kedatangannya di Wolio, Sayyidi Raba lalu melanjutkan syiar Islamnya di Pulau Muna dekat Pulau Buton. Masyarakat Lohia di Muna meriwayatkan bahwa cikal bakal tanaman kelor di Muna berawal dari tongkat Sayyidi Raba yang ditancapkan di tanah dan kemudian menjadi tanaman kelor.

Sekalipun masyarakat Wolio umumnya beragama Islam, namun sinkretisme antara agama dan budaya lokal juga banyak ditemukan. Selain sebagian masyarakat masih percaya dengan 
adanya animisme, dinamisme, juga masih hidup berbagai tabu dalam masyarakat. Salah satu tabu yang masih dipraktikkan yakni tabu terkait dengan tanaman kelor. Sejumlah tabu terkait dengan kelor pada masyarakat Wolio: tidak melangkahi batang kelor, tidak memasukan kelor di dalam rumah saat keluarga sedang berkabung, tidak boleh memukulkan tangkai kelor pada anak kecil, tidak boleh perempuan yang sedang haid memetik kelor, dan lain-lain.

\section{Etnobotani Wolio}

Studi etnobotani membuktikan bahwa pengetahuan penduduk asli (native) mengenai berbagai tanaman tidak kalah dengan pengetahuan para ahli etnobotani. Bahkan dengan pengalaman panjang yang diwariskan secara turun temurun, lalu melahirkan sudut pandang-sudut pandang yang kaya terkait dengan kegunaan praktis tanaman, maupun kegunaan tanaman sebagai simbol (Furst 1976; Prance, Campbell, dan Nelson 1977:131; Munyanziza dan Sarwatt 2003:455). Dengan demikian cakupan studi etnobotani juga menyangkut kepercayaan mengenai tanaman-tanaman tertentu.

Dalam etnobotani masyarakat Wolio, tanaman yang tumbuh di alam diklasifikasikan atas: pohon berkayu (puuna kau), tanaman pangan (penembula), dan rumput (rumpu). Secara harfiah puna kau dalam bahasa Wolio berasal dari kata $p u$ yang berarti pohon, ditambah prefiks na yang berarti nya, dan kata kau yang berarti kayu. Dengan demikian yang termasuk dalam klasifikasi puuna kau adalah semua tumbuhan yang batangnya berkayu, berperawakan besar dan tinggi, berakar tunggang, dan merupakan tanaman jangka panjang. Tanaman yang dimaksud antara lain: jati (dhati), kayu besi (wola), kapuk/randu (kapa jawa), randu alas (kawukawu), nangka (tiwadha), jaran (kaujawa), termasuk kelor (kaudhawa). Masyarakat Wolio memanfaatkan batang (bhata) pohon berkayu keras terutama untuk: bahan bangunan rumah, perahu, meubel, peralatan rumah tangga, pagar, dan tangga. Sedangkan bagian lain dari pohon, terutama ranting-ranting lazim digunakan sebagai kayu bakar. Batang, serbuk, dan kulit kayu pohon tertentu sebagaimana nangka, bakau, saontiri dapat pula digunakan sebagai pewarna alami tekstil. Di antara tanaman yang diklasifikasikan sebagai puna kau ada pula yang digunakan sebagai bahan makanan, baik sebagai buah, sayur, bumbu dapur, maupun obat.

Dalam bahasa Wolio, istilah penembula berasal dari kata pene yang berarti naik, dan mbula yang berasal dari pemendekan kata pombula yang berarti menanam. Dengan demikian penembula adalah tumbuhan yang sengaja ditanam dari bibit (wine). Bibit yang telah ditanam di dalam tanah lalu tumbuh dengan cara membuka naik ke atas. Istilah penembula dalam arti khusus adalah semua tanaman yang sengaja ditanam untuk menghasilkan bahan makanan sehari-hari sepanjang tahun. Bibit yang akan menghasilkan bahan makanan sehari-hari baik yang berasal dari biji, stek batang, rimpang, dan umbi. Penembula sebagai bahan makanan sehari-hari, ada yang dapat dimakan secara langsung dan ada pula yang harus terlebih dahulu diolah. Bahan mentah makanan yang berasal dari tanaman, selain untuk makanan pokok (kinande) terbuat dari jagung (kaitela), ubikayu (wikau), ubijalar (kaowi-owi), gembili (owi), dan beras (bae), juga untuk sayur (tawana kau). 
Berbagai tanaman yang diklasifikasikan sebagai penembula dapat menghasilkan buah-buahan (bhakena kau), dan bumbu dapur (rampa). Penembula selain dibudidayakan di tanah pekarangan (kayina-yinawu) juga di kebun (nawu). Bagi masyarakat Wolio, penembula merupakan tanaman yang bibit (wine) dan lahan (tana)nya dipersiapkan sebelumnya. Selain itu, penembula akan mendapatkan perawatan selama hidupnya. Hal ini karena penembula sangat diharapkan untuk tumbuh dan berkembang, agar dapat menghasilkan bahan makanan sehari-hari.

Dalam istilah etnobotani Wolio, tumbuhan yang rendah, kecil, liar, dan tidak dimakan oleh manusia disebut rumpu. Sekalipun rumput (rum$p u$ ) tidak dimakan akan tetapi dapat bermanfaat sebagai: obat, racun, makanan ternak, pewarna, dan sebagainya. Rumput tidak dikonsumsi manusia karena sebagian dianggap dapat membahayakan. Hal ini karena rumput terkait dengan tumbuhan liar yang dapat melukai karena berduri atau tajam. Selain itu, ada pula yang berbau menyengat, busuk atau tidak sedap, pahit, kesat, dan menimbulkan rasa gatal pada kulit.

Meskipun tanaman kelor sudah lama dikenal masyarakat Indonesia, akan tetapi tanaman ini sesungguhnya berasal dari India tepatnya di Agra dan Oudh, di sebelah selatan Pegunungan Himalaya (Suwahyono 2008:11). Eksistensi kelor di Wolio diduga terkait dengan kedatangan para para pedagang rempah-rempah di masa lalu dari Malaka ke Maluku yang transit di Pulau Buton. Selain itu ada pula yang mengatakan kelor diperkenalkan oleh Belanda. Kelor dalam klasifikasi etnobotani Wolio dimasukkan dalam klasifikasi tanaman berkayu (puuna kau), dan tanaman pangan (penembula).
Tanaman kelor masuk dalam klasifikasi puuna kau karena memiliki fisik pohon yang besar, tinggi, berkayu sekalipun tidak tergolong kayu berkualitas. Kelor juga diklasifikasikan sebagai penembula karena kelor selama ini digunakan sebagai bahan makanan sehari-hari yaitu sebagai sayur. Sayur kelor yang dikonsumsi umumnya berwujud sayur bening, biasanya dipadupadan bersama bahan sayur lainnya seperti: jagung putri (kaana-ana), pepaya muda (kapaeya), kembang pepaya jantan (kambana kapaeya), kembang dan pucuk labu (kambana paratukala), gambas (patola), kacang panjang (lawue). Oleh karena tanaman kelor merupakan tanaman yang sengaja ditanam (pombula) dan untuk dimakan, maka sangat jelas jika tanaman ini merupakan penembula.

\section{Tanaman Kelor di Kalangan Masyarakat Wolio}

Dalam bahasa Wolio tanaman kelor (Moringa oleifera) disebut dengan nama kaudhawa. Istilah ini berasal dari dua kata, yaitu "kau" dan "dhawa". Kata kau berarti kayu, atau pohon berkayu, sedangkan dhawa berarti perekat atau lem yang berasal dari getah (polo) pohon. Dengan kata lain kaudhawa adalah pohon berkayu yang bergetah, dan dapat digunakan sebagai perekat/lem. Perekat dari getah kelor hanya lazim digunakan untuk merekatkan benda lunak terutama jenis kertas, dan benang.

Istilah dhawa untuk menyebut bahan perekat dari pohon kelor, dewasa ini semakin tidak dikenal lagi oleh generasi muda Wolio. Bahkan, istilah ini semakin terancam punah karena hanya digunakan oleh orang-orang tua. Selain karena istilah dhawa merupakan bahasa tua atau lama, 
istilah ini berubah karena perekat yang semula dari getah batang kelor (dhawa) tergeser oleh perekat yang terbuat dari tepung tapioka, sagu, dan beras yang diistilahkan pidha. Pidha dalam bahasa Wolio berarti tempel, lengket.

Fenomena berbahasa di kalangan generasi muda sekarang untuk menyebut perekat kertas kini tidak menggunakan istilah dhawa lagi. Bahkan istilah pidha yang menggeser dhawa juga telah tergeser oleh istilah lemu. Istilah lemu yang populer sekarang, diadopsi dari istilah lem. Oleh karena dalam bahasa Wolio tidak mengenal konsonan di akhir kata, maka lem diberi vokal u sehingga berbunyi lemu. Penggunaan istilah lemu sekarang ini seturut dengan mudahnya mendapatkan perekat siap pakai yang dijual di toko atau kios. Istilah lemu selain menggeser istilah pidha, juga bermakna lebih luas yaitu mencakup perekat yang terbuat tepung dan perekat yang diproduksi oleh pabrik. Selain itu, lemu menunjuk pula pada semua jenis dan peruntukan perekat. Jangkauan peruntukan istilah lemu meliputi perekat untuk: kertas, plastik, kayu, logam, kaca, hingga kulit asli dan sintetis. Evolusi jenis bahan perekat di tengah masyarakat Wolio telah memberi pengaruh pada perubahan istilah atau nama bagi perekat yang selama ini digunakan. Evolusi istilah yang dimaksud yaitu: dhawa, pidha, dan lemu.

Bagi masyarakat Wolio untuk membudidayakan tanaman kelor tidak memerlukan perhatian khusus sebagaimana tanaman lain. Tanaman ini juga termasuk tanaman yang mempunyai daya juang dan adaptasi yang tinggi karena mampu bertahan di alam yang keras, dan produktif sepanjang musim. Menanam kelor di celah-celah batu, tanah berkapur, tanah berpasir dekat pantai adalah merupakan pemandangan yang lazim ditemukan di Baubau. Di antara sekian pilihan tanaman yang mampu menghasilkan bahan sayur bagi masyarakat Wolio, tanaman kelor merupakan tanaman yang paling banyak populasinya, dan paling digemari lidah masyarakat Wolio. kehidupan masyarakat Wolio. Internalisasi kelor sejak dini dalam wujud sayur telah menjadikan kelor sulit dipisahkan dalam kehidupan masyarakat Wolio. Tidak jarang di daerah rantau pun orang Wolio akan mencari kelor. Hal serupa mirip halnya dengan masyarakat Jawa yang selalu merindukan tempe, atau pete.

Sekalipun kelor dominan dijadikan sebagai sayur sehari-hari, namun tanaman ini juga digunakan untuk keperluan lain. Beberapa guna tanaman kelor menurut pandangan masyarakat Wolio yaitu: sebagai obat untuk menyembuhkan berbagai macam penyakit dan penawar racun. Selain hal yang telah disebutkan kelor berguna pula sebagai pengawet alami makanan, karbit alami buah, pewarna alami tekstil dan makanan, penghilang bau amis, dan lain-lain. Jauh sebelum sistem pengobatan medis hadir di tengah masyarakat Wolio, kelor telah menjadi tumpuan harapan untuk mendapatkan penyembuhan berbagai penyakit. Sangat disayangkan generasi muda Wolio kini lebih tertarik berobat secara medis, dan cenderung mengabaikan pengobatan tradisional berbasis kelor.

Sekalipun tanaman kelor telah lama dikenal, akan tetapi sejauh ini belum ada upaya masyarakat Wolio untuk menciptakan produk turunan kelor. Produk aneka makanan ringan, minuman instant, obat, dan kosmetik berbasis kelor sebagaimana yang diiklankan di medsos dan 
lain-lain, agaknya belum menginspirasi masyarakat untuk berbuat yang sama sekalipun mengenai kegunaan kelor telah lama dipraktikkan. Masyarakat Wolio lebih tertarik menggunakan kelor terutama sebagai sayur dan ramuan obat.

\section{Sistem Klasifikasi Kelor}

Tanaman kelor dalam etnobotani Wolio diklasifikasikan atas kelor perempuan dan kelor laki-laki. Pengklasifikasian tersebut didasarkan atas adanya perbedaan baik yang nampak secara fisik maupun yang non fisik. Penamaan kelor yang disertai penjelasan kata perempuan dan laki-laki menujukkan pula ada genderisasi kelor dibalik pengklasifikasiannya.

\section{Kelor Perempuan (Kaudhawa Bhawine)}

Kelor perempuan disebut demikian karena secara fisik tangkai daunnya berwarna merah (malei). Warna merah yang dominan terkadang nampak merah hati, merah kecoklatan, dan merah keunguan. Oleh karena itu warna merah yang dimaksud terkadang nampak merah gelap atau merah cerah. Warna merah pada tangkai yang kontras dengan warna hijau pada daun menjadi petunjuk bila kelor yang demikian bergender perempuan. Warna merah pada tangkai kelor secara simbolik dimaknai sebagai perempuan. Menurut Artha dan Ahimsa-Putra (2004:29) simbol adalah segala sesuatu yang dimaknai, sesuatu yang mengacu pada sesuatu

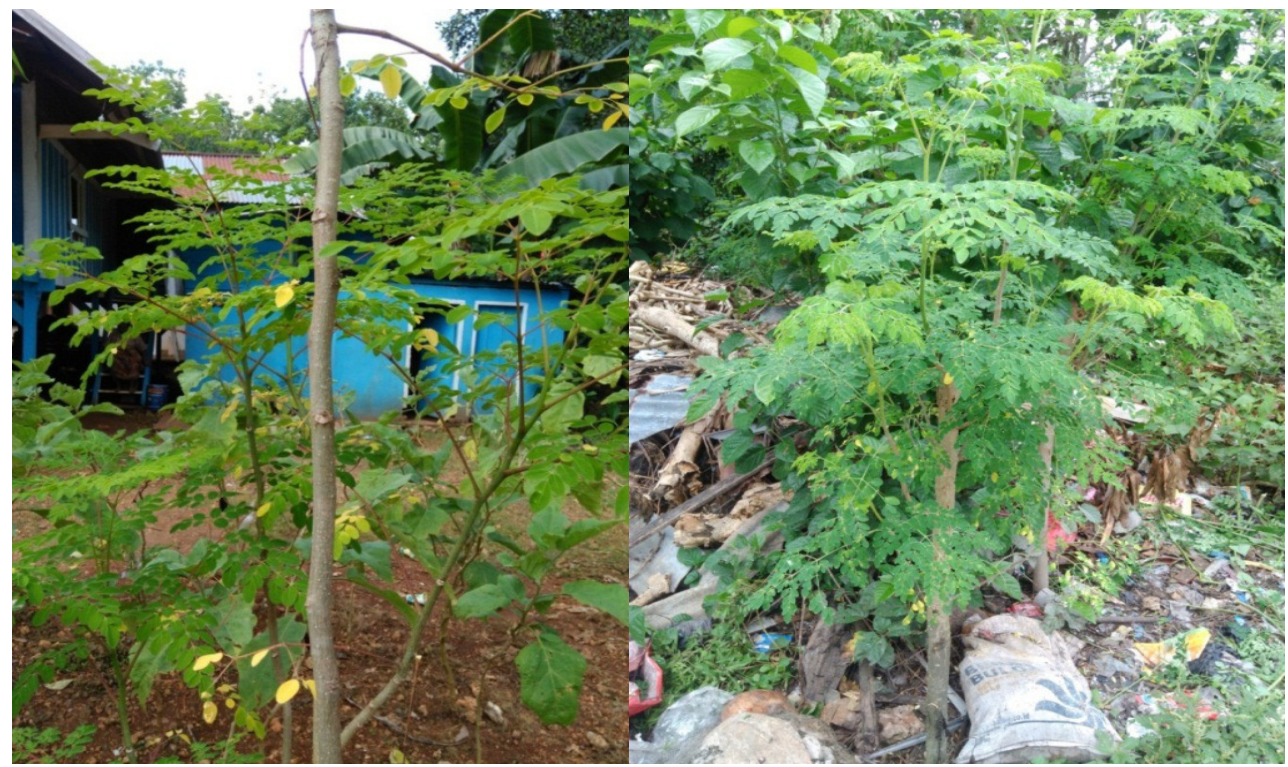

Gambar. 1

Kelor merah-kelor perempuan (kiri), kelor putih-kelor-laki-laki (kanan) 
yang lain. Dengan demikian tangkai kelor merah yang dijadikan rujukkan untuk memaknai kelor yang demikian sebagai kelor perempuan sekaligus sebagai simbol yang bermakna. Secara kultural warna merah pada kelor diasosiasikan pula sebagai darah haid. Oleh karena itu, hanya kelor perempuan yang berwarna merah. Dengan demikian ada saling hubung antara warna merah, darah, dan perempuan.

Selain warna merah pada tangkai, terdapat pula bentuk dan ukuran terkait dengan kelor yang dimaknai sebagai simbol perempuan. Hal yang dimaksud antara lain: pokok pohon yang lebih rendah dan kecil, cabang dan ranting yang berukuran kecil, dan bentuk ranting yang meliuk dan menjuntai. Ciri fisik pohon yang demikian diasosiasikan sebagai representasi tubuh perempuan dan sikap perempuan yang lemah dan lembut. Dengan demikian kelor adalah metafor manusia. Deskripsi mengenai pohon yang demikian, menunjukkan bahwa kelor dianalogikan sebagaimana tubuh manusia, karena masing-masing bagian tubuh kelor telah ditempeli makna.

Umumnya kelor yang dibudidayakan secara alami akan berbeda ukuran helai daunnya antara kelor perempuan dengan kelor laki-laki. Kelor perempuan ukuran lembar daunnya lebih kecil dibanding kelor laki-laki. Demikian pula ukuran buahnya lebih pendek dari ukuran buah yang dihasilkan kelor laki-laki. Demikian pula buah yang dihasilkan kelor perempuan biasanya lebih sedikit. Menurut pengamatan dan informasi populasi pohon kelor perempuan lebih sedikit dibanding kelor laki-laki. Oleh karena itu, jenis kelor ini tergolong langka.
Secara kualitatif, kelor perempuan dianggap lebih enak daunnya jika disayur. Menurut pandangan masyarakat bahwa daun kelor perempuan bila dikunyah halus, sarinya akan terasa seperti santan. Sari kelor yang berasa santan saat disayur adalah kelor yang dianggap paling enak. Hal ini juga terefleksikan dalam kuliner masyarakat Wolio, bahwa dalam suguhan makanan dalam acara pesta, ritual, selalu menyuguhkan makanan bersantan. Sebaliknya makanan sehari-hari minim santan. Menyuguhkan makanan bersantan adalah juga bentuk penghormatan, simbol enak, dan istimewa.

Bagi masyarakat Wolio ada kepercayaan bahwa kelor perempuan atau kelor merah adalah kelor yang sangat mujarab, ampuh jika digunakan untuk mengobati berbagai macam penyakit. Oleh karena itu, kelor jenis ini sering dicari sebagai bahan obat. Terkait dengan warna merah keunguan pada tangkai daun kelor perempuan, hal ini analog dengan tanaman ubi jalar berwarna ungu. Richana (2012) menjelaskan bahwa ubi jalar berwarna ungu mengandung senyawa antosianin. Antosianin sangat bermanfaat bagi kesehatan tubuh karena berfungsi sebagai antioksidan, antihipertensi, pencegah gangguan fungsi hati, jantung koroner, kanker, dan penyakit-penyakit generatif. Antosianin juga mampu menghalangi laju perusakan sel radikal bebas akibat nikotin, polusi udara, dan bahan kimia lainnya. Langkanya populasi kelor merah selain pertumbuhannya lembih lambat, produksi daun buah yang minim, juga karena sangat sering dieksploitasi sebagai bahan obat atau sekedar dijadikan sayur sehari-hari 
guna mencegah berbagai macam penyakit. Penulis menduga mengapa kelor merah dianggap ampuh selama ini karena lebih banyak mengandung senyawa antosianin dibanding kelor laki-laki.

\section{Kelor Laki-laki (Kaudhawa Umane)}

Berbeda halnya dengan kelor perempuan, kelor laki-laki memiliki ciri fisik tangkai daun yang berwarna hijau, yang kemudian disebut putih (maputi). Dengan demikan ada peminjaman nama warna untuk menempatkan warna putih sejajar dengan merah. Dengan demikian warna merah sebagai representasi perempuan dapat berpasangan dengan warna putih sebagai representasi laki-laki. Kelor laki-laki disebut demikian karena tangkainya tidak berwarna merah, akan tetapi putih. Warna putih pada tangkai kelor diasosiasikan sebagai mani laki-laki. Dengan demikian ada penyetaraan makna pada masing-masing jenis kelor, jika perempuan darah haid maka laki-laki air mani. Kelor laki-laki mempunyai pokok pohon yang besar, tinggi, dan tegak. Wujud yang demikian diasosiasikan sebagai laki-laki yang gagah, kuat, dan melindungi.

Kelor yang dibudidayakan secara alami menunjukkan jika kelor laki-laki ukuran lembar daunnya umumnya lebih besar dibanding kelor perempuan. Demikian pula ukuran buahnya nampak lebih panjang dari ukuran buah yang dihasilkan kelor perempuan. Jumlah buah yang dihasilkan kelor laki-laki dewasa, menurut pengalaman masyarakat selama ini biasanya lebih banyak hingga mencapai di atas seratus buah. Tidak jarang karena sarat dengan buah, cabang dan ranting sering kali mengalami patah (masongka). Berbeda halnya dengan populasi pohon kelor perempuan, populasi kelor laki-laki yang tumbuh di daerah ini lebih banyak jumlahnya. Selain itu kelor laki-laki lebih mudah tumbuh, dan jumlah produksi daun dan buahnya juga lebih banyak. Sekalipun produksi daun kelor laki-laki lebih banyak, akan tetapi rasa daunnya kalah enak dibanding jenis kelor perempuan. Oleh karena itu daun kelor laki-laki dianggap berkualitas lebih rendah.

Sekalipun produksi daun dan buah kelor lebih banyak, populasi lebih banyak, pertumbuhan lebih cepat, akan tetapi jika daunnya digunakan sebagai obat maka tidak akan semujarab dan seampuh kelor perempuan. Akan tetapi karena kelor perempuan semakin langka, dengan terpaksa daun kelor laki-laki digunakan pula sebagai obat. Berdasarkan klasifikasi yang dikonstruksi masyarakat lalu dibuat perbandingan kelor perempuan dan laki-laki sebagaimana tabel berikut ini.

\section{Kelor: Klasifikasi, Simbol, dan Makna}

Metafora kelor sebagaimana manusia menunjukkan bahwa kelor menjadi salah satu tanaman yang penting dalam kehidupan masyarakat Wolio. Selain itu, juga menjadi rujukan di antara tanaman lain yang selama ini digunakan. Karakteristik kelor baik dalam hal warna, bentuk, ukuran, dan rasa, bukan saja hadir sebagai ciri yang membedakan kelor dengan tanaman lain akan tetapi juga mempunyai makna kultural. Oleh karena itu, baik warna kelor merah dimetaforkan, ukuran dan bentuk, mau pun rasa daun kelor juga mempunyai makna. 
Tabel 1.

Matriks klasifikasi kelor menurut pandangan masyarakat Wolio

\begin{tabular}{lll}
\hline \multirow{2}{*}{ No } & \multicolumn{2}{c}{ Jenis Kelor } \\
\cline { 2 - 3 } & Perempuan & Laki-laki \\
\hline 1 & Tangkai berwarna merah & Tangkai berwarna putih \\
2 & Ukuran tangkai daun kecil dan pendek & Ukuran tangkai daun besar besar dan panjang \\
3 & Ukuran daun lebih kecil & Ukuran daun lebih besar \\
4 & Ukuran buahnya pendek & Ukuran buahnya panjang \\
5 & Berbuah sedikit & Berbuah banyak \\
6 & Pohonnya kecil dan agak pendek & Pohonnya besar dan tinggi \\
7 & Cabang dan ranting agak menjuntai, meliuk & Cabang dan ranting tegak, kaku \\
8 & Daunnya enak terasa bersantan & Daunnya kurang enak/tidak terasa bersantan \\
9 & Mujarab sebagai obat & Kurang mujarab sebagai obat \\
7 & Langka & Banyak \\
\hline
\end{tabular}

Sumber: diolah berdasarkan data primer, 2019

Menurut Spradley (1997: 251) makna adalah sejumlah simbol dalam kebudayaan yang saling terhubung satu dengan yang lain. Bagi masyarakat Wolio warna, ukuran dan bentuk, jumlah, dan rasa, khasiat tanaman kelor yang saling dipertentangkan atau berlawanan adalah simbolsimbol yang penting untuk diterjemahkan.

\section{Warna}

Kelor merah dimetaforkan sebagai perempuan karena selain merepresentasikan ciri fisik perempuan, juga sebagai simbol darah haid. Sebaliknya kelor putih yang dimetaforkan sebagai laki-laki selain merepresentasikan fisik laki-laki, juga sebagai simbol air mani. Darah haid dan air mani yang diposisikan hadir setara meski pun berbeda warna, secara tersirat bahwa dalam logika berpikir masyarakat Wolio berupaya menciptakan keseimbangan meski dalam wujud yang berbeda dalam relasi antar gender. Jika laki-laki disimbolkan dengan warna pilihan tertentu, maka perempuan pun demikian pula halnya. Dalam konteks ini perempuan hadir dengan warna yang berbeda dengan laki-laki, dan sekaligus perepresentasikan wujud dan makna warna yang berlawanan. Dengan demikian warna yang beroposisi (merah vs putih) selalu berusaha dihadirkan agar dapat berpasangan, dan dapat saling melengkapi. Perbedaan bukan untuk dipertentangkan namun sebaliknya untuk dapat saling melengkapi dan mempersatukan.

\section{Ukuran dan Bentuk}

Ukuran dan bentuk pohon kelor laki-laki yang berlawanan dengan kelor perempuan menyimbolkan jika laki-laki idealnya harus gagah, perkasa, dan melindungi. Sebaliknya kelor perempuan yang kecil, pendek, dengan cabang dan ranting yang menjuntai agak meliuk adalah simbol perempuan Wolio yang idealnya diharapkan untuk bersikap: lemah lembut, halus, dan jauh dari sosok perkasa. Pada kelor laki-laki, cabang dan ranting yang besar, tegak, lurus, dan 
besar adalah simbol: jantan, tegas, dan tangguh. Simbol yang diberi makna sebagaimana yang dikemukakan juga mengandung harapan agar laki-laki harus menampakkan sifat dan sikap yang maskulin, bukan sebaliknya feminin sebagaimana para perempuan. Laki-laki harus melindungi perempuan, dan bukan sebaliknya. Oleh karena itu, laki-laki yang dilindungi perempuan atau dinafkahi perempuan biasanya harga dirinya akan terusik.

Bila dibandingkan dengan kelor laki-laki, maka ukuran tangkai dan helai daun kelor perempuan umumnya lebih pendek dan kecil. Gambaran fisik yang demikian adalah juga sebagaimana fisik perempuan yang secara kuantitas dianggap di bawah laki-laki. Sebaliknya kelor laki-laki, selain ukuran tangkainya lebih panjang, juga ukuran daunnya lebih besar. Ukuran yang demikian sekaligus simbol yang dimaknai sebagai superioritas laki-laki atas perempuan.

\section{Jumlah}

Jumlah buah kelor yang diproduksi pohon kelor perempuan biasanya lebih sedikit dibanding kelor laki-laki. Kenyataan ini lalu dianalogikan sebagaimana alat reproduksi perempuan yang dibatasi oleh waktu. Terbatas dalam memproduksi buah, dimaknai pula sebagaimana produktifitas tubuh perempuan yang terhenti karena alasan biologis (haid, dan menopause). Sebaliknya laki-laki tanpa limit produksi sebagaimana perempuan.

\section{Rasa}

Pandangan kolektif masyarakat yang mengklaim bahwa rasa kelor merah lebih enak jika dibandingkan dengan kelor putih, hal ini membuktikan pula adanya kesepakatan kultural untuk mengakui keunggulan atau keistimewaan perempuan. Pandangan yang demikian menegaskan pula bahwa meski pun dalam beberapa hal perempuan terbatas secara kuantitas dibandingkan laki-laki, namun perempuan secara kualitas tidak dapat diremehkan. Rasa kelor perempuan yang lebih enak adalah simbol pengakuan atas kelebihan-kelebihan perempuan yang perlu diapresiasi. Kasih sayang, perhatian, kesabaran, ketekunan, dan sifat-sifat naluriah lainnya dari perempuan bukan saja mampu menciptakan rasa nyaman, bahagia, namun juga mampu sebagai pemelihara dan penyelamat keluarga.

Adanya kontruksi budaya yang menempatkan posisi perempuan dan laki-laki selalu beroposisi namun berpasangan, bagi penulis bukanlah sesuatu yang merepresentasikan kekalahan perempuan sekali pun jelas sangat patriarki. Akan tetapi, oposisi diciptakan untuk saling melengkapi agar dapat bekerjasama dan saling melengkapi. Hal ini seturut dengan Dzuhayatin, Rachman, dan Umar (2002) yang mengatakan dalam budaya patriarki laki-laki adalah manifestasi dari yang lebih mulia dan perempuan yang melengkapi laki-laki. Akan tetapi, baik laki-laki terlebih perempuan tuntutan kesetaraan yang dikumandangkan tidak lagi memuliakan salah satu dari keduanya melainkan memuliakan keharmonisan keduanya dalam kesederajatan. 
Meskipun kelor perempuan secara kultural lebih dikonstruksi, disimbolkan sebagai pihak yang tersubordinasi, akan tetapi ada pengakuan kultural bahwa perempuan menyimpan energi yang dasyat. Hal ini sebagaimana analogisasi bahwa kelor perempuan lebih berdaya ampuh, lebih mujarab sebagai obat jika dibandingkan dengan kelor laki-laki. Kelor perempuan dianggap lebih mujarab jika digunakan untuk mengobati penyakit. Adanya pengakuan tersebut sekaligus menyiratkan bahwa perempuan adalah simbol penyembuh, dan penyelamat. Perempuan adalah juga sumber dan tumpuan banyak harapan.

Adanya keberpihakan budaya Wolio atas perempuan mengandung makna bahwa ada upaya menjalin relasi gender yang saling imbang. Dalam konteks ini meskipun kontruksi sosial budaya saling beroposisi namun ada ruang untuk menciptakan keseimbangan dan kesederajatan. Dengan demikian campur tangan kebudayaan atas relasi gender pada masyarakat Wolio antara lain tercermin sebagaimana dalam maknamakna yang tersirat dalam klasifikasi kelor.

Adanya maksud dan tujuan sebagaimana yang tersirat dalam klasifikasi kelor menujukkan bahwa ada harapan kolektif dibalik klasifikasi. Perempuan dengan citra feminin dan sebaliknya laki-laki dengan citra maskulin. Perempuan dengan kekurangan dan keterbatasannya mempunyai sisi lain yang tidak kalah istimewa. Demikian pula laki-laki dengan kelebihan dan keistimewaannya pada sisi lain memiliki pula kekurangan. Pada akhirnya kekurangan dan kelebihan yang dipertemukan akan menuju pada satu titik yang sama. Perempuan dan laki- laki berbeda untuk saling menyempurnakan menuju kesetaraan yang berawal dari perbedaan.

Selain klasifikasi kelor perempuan dan lakilaki, dalam etnobotani kelor masyarakat Wolio terdapat pula klasifikasi lain seperti: kelor yang dibudidayakan dan kelor liar, kelor enak dan kelor tidak enak. Kelor yang dibudidayakan adalah kelor yang sengaja bibit dan lahan tempat tumbuhnya dipersiapkan. Selain itu selama hidup mendapat perawatan karena diharapkan dapat mendatangkan hasil untuk dinikmati. Sebaliknya kelor liar adalah kelor yang tidak sengaja ditanam, akan tetapi tumbuh karena campur tangan hewan, atau angin. Kelor liar biasanya tumbuh di hutan, tebing, dan jarang berinteraksi dengan manusia. Kelor yang tumbuh di tempat yang demikian tidak akan dikonsumsi manusia karena dianggap tumbuh di arena bebas yang liar. Selain itu, rasa kelor yang dihasilkan akan pahit (mapai), dan tidak lunak (makaha). Kelor yang demikian baru layak dikonsumsi manakala dipangkas dan tumbuh daun baru yang lunak Perlakuan yang demikian dianalogisasikan sebagaimana manusia yang dimanusiakan melalui campur tangan kebudayaan.

Kelor yang diklasifikasikan sebagai kelor enak yaitu kelor merah atau perempuan, kelor yang tumbuh di batu, dan kelor yang dipetik di musim kemarau meski pun keduanya adalah kelor lakilaki. Kelor dengan klasifikasi yang demikian dikatakan enak karena bersantan. Dengan demikian kelor yang bersantan tidak terbatas pada kelor perempuan saja, akan tetapi berlaku pula untuk laki-laki. Di sini nampak bahwa sesuatu yang terkait dengan santan selalu 
dianggap enak, dan yang enak dapat ditemukan pula pada kelor laki-laki. Dengan demikian ada kesamaan dan keseimbangan. Selain tiga klasifikasi di atas, kelor yang sering dipangkas juga dianggap enak meski pun juga merupakan kelor laki-laki. Berbeda dengan kelor yang enak karena sarinya berasa santan. Kelor yang sering dipangkas dikatakan enak karena lunak, tidak berbau (mangimbo), serta tidak pedas. Hal ini sebaliknya dengan kelor yang tidak pernah dipangkas sebagaimana di hutan. Dengan demikian semakin sering kelor berinteraksi dan mendapat perlakuan baik dari manusia, maka kelor akan memberikan kualitas yang baik. Hal yang sama juga dapat terjadi pada manusia, karena hanya mereka yang berinteraksi dan mendapat perlakuan baik yang akan menunjukkan kualitas baiknya sebagai manusia.

\section{Kesimpulan}

Masyarakat Wolio berpandangan bahwa tanaman kelor adalah tanaman yang bukan saja adaptif dan produktif bagi kehidupan, namun juga multiguna. Begitu dekat dan intensnya masyarakat Wolio berinteraksi dengan kelor, sehingga kelor bukan saja diklasifikasikan tetapi juga dimaknai. Tanaman kelor telah menginspirasi leluhur masyarakat Wolio belajar banyak hal tentang hidup dan kehidupan. Kelor telah menuntun masyarakat Wolio dalam menata kehidupan sosial mereka khususnya dalam relasi antar gender.

Sistem klasifikasi kelor yang mengacu pada ciri-ciri fisik dan non fisik sebagaimana perbedaan warna, bentuk, ukuran, dan rasa telah melahirkan pandangan tersendiri di kalangan masyarakat Wolio. Oleh karena itu, dalam etnobotani masyarakat Wolio tanaman kelor bukan hanya menyangkut hal yang kuantitatif akan tetapi juga kualitatif. Domain warna, bentuk, ukuran, rasa dan lainnya yang diberi makna sesungguhnya merefleksikan bagaimana pandangan masyarakat Wolio dalam memaknai dunia mereka.

Genderisasi kelor sebagaimana dalam sistem klasifikasi kelor secara tersurat mengajarkan bagaimana mengenali tanaman ini secara lebih detail, dan secara tersirat mengajarkan masyarakat Wolio bagaimana menata relasi gender yang terilhami oleh tanaman kelor. Dengan demikian tanaman "kelor" sebagai bagian dari etnobotani masyarakat Wolio terpilih di antara tanaman lainnya karena dianggap layak untuk merepresentasikan cita-cita leluhur menuju kesetaraan dari dua hal yang berbeda. Dengan demikian klasifikasi kelor menurut sudut pandang masyarakat Wolio adalah juga sebuah ideologi yang menata relasi dari dua gender yang berbeda.

Relasi gender sebagaimana yang tersirat dalam narasi dan metafor kelor masyarakat Wolio, dapat menjelaskan bahwa kesetaraan gender tidak selamanya harus dengan wujud dan nilai yang sama. Ini berarti pula bahwa sama atau setara tidak berarti harus berwujud simetris segalanya. Akan tetapi, sama atau setara di sini bisa saja berwujud asimetris. Perbedaan atau ketidaksamaan akan menyatu sempurna bila keduanya bersama untuk saling melengkapi.

Pada akhirnya melalui tanaman kelor, sebagian dunia masyarakat Wolio dapat terbuka. Kelor sebagai "jendela" memahami masyarakat 
Wolio juga telah menjelaskan bagaimana upaya budaya menyeimbangkan berbagai perbedaan antara laki-laki dan perempuan menuju kesetaraan yang humanis sebagaimana yang diharapkan masyarakat Wolio.

\section{Acknowledgement}

Penulis mengucapkan terima kasih kepada Prof. Dr. Heddy Shri Ahimsa-Putra, M.A., M.Phil selaku promotor yang telah membimbing penulis mengenai tema-tema Etnobotani Kelor di kalangan masyarakat Wolio. Ucapan terima kasih juga penulis sampaikan kepada Dr. Lono Lastoro Simatupang, M.A., selaku co-promotor yang telah meluangkan waktu untuk berdiskusi mengenai tema yang sama.[]

\section{Daftar Pustaka}

Artha, Arwan Tuti dan Heddy Shri Ahimsa-Putra. 2004. Jejak Masa Lalu: Sejuta Warisan Budaya. Yogyakarta: Kunci Ilmu.

Berlin, Brent, Dennis E. Breedlove, dan Peter H. Raven. 1968. "Covert Categories and Folk Taxonomies." American Anthropologist 70(2):290-99.

Butts, W. K. 1946. “Classification.” Bios 17(1):5159.

Dzuhayatin, Siti Ruhaini, Budhy Munawar Rachman, dan Nasaruddin Umar. 2002. Rekonstruksi Metodologis Wacana Kesetaraan Gender dalam Islam. 1 ed. Yogyakarta: Pustaka Pelajar dan PSW IAIN Sunan Kalijaga.

Fleuret, Anne. 1980. "Nonfood uses of plants in Usambara." Economic Botany 34(4):32033.
Ford, Richard I. 1985. "Anthropological Perspective of Ethnobotany in the Greater Southwest." Economic Botany 39(4):400415.

Frisch, Jack A. 1968. "Maricopa Foods: A Native Taxonomic System." International Journal of American Linguistics 34(1):16-20.

Furst, Peter T. 1976. Hallucinogens and Culture. Albany, NY.: Chandler \& Sharp.

Ghosal, Abhijit dan Sovan Chakraborty. 2009. "Cognition and Perception of Environment among the Munda." Indian Anthropologist 39(1-2):136-44.

Glick, Leonard B. 1964. "Categories and Relations in Gimi Natural Science." American Anthropologist 66(4):273-80.

Harris, Eric S. J. 2008. "Ethnobryology: Traditional Uses and Folk Classification of Bryophytes." https://doi.org/10.1639/00072745(2008)111[169:ETUAFC]2.0.CO;2 111(2):169-217.

Jahn, Samia Al Azharia. 1991. "The Traditional Domestication of a Multipurpose Tree Moringa stenopetala (Bak.f.) Cuf. in the Ethiopian Rift Valley." Ambio 20(6):24447.

Lira, Rafael dan Javier Caballero. 2002. "Ethnobotany of the wild Mexican Cucurbitaceae." Economic Botany 56(4):380-98.

Munyanziza, E. dan S. V. Sarwatt. 2003. "Evaluation of Moringa Oleifera for Food Security and Environmental Rehabilitation in Tanzanian Rural Areas." Journal of Tropical Forest Science 15(3):450-56.

Perchonock, Norma dan Oswald Werner. 1969. "Navaho Systems of Classification: Some Implications for Ethnoscience." Ethnology 8(3):229-42. 
Prance, Ghillean T., David G. Campbell, dan Bruce W. Nelson. 1977. "The ethnobotany of the Paumarí Indians." Economic Botany 31(2):129-39.

Richana, Nur. 2012. Ubi Kayu dan Ubi Jalar: Botani - Budidaya Teknologi Proses Teknologi Pascapanen. Bandung: Nuansa.

Senchina, David S. 2006. "Ethnobotany of Poison Ivy, Poison Oak, and Relatives (Toxicodendron spp., Anacardiaceae) in America: Veracity of historical accounts." Rhodora 108(935):203-27.

Spindler, George dan Louise Spindler. 1985. "Ethnography: An Anthropological View." Educational Horizons 63(4):154-57.
Spradley, James. 1997. Metode Etnografi (Ethnographic Interview). terj. M. Z. Elizabeth. Yogyakarta: PT. Tiara Wacana.

Suwahyono, Untung. 2008. Khasiat Ajaib Si Pohon Gaib - Mengupas Rahasia Tersembunyi Pohon Kelor. Yogyakarta: Andi Publisher.

Tedlock, Barbara. 2011. "Observasi Partisipan dan Kemunculan Etnografi Publik." in The Sage Handbook of Qualitative Research 1, diedit oleh N. K. Denzin dan Y. S. Lincoln. Yogyakarta: Pustaka Pelajar.

Young, Kim J. 2007. Ethnobotany. New York: Chelsea House. 